\title{
ANALISIS LEVEL LITERASI STATISTIK MAHASISWA CALON GURU MATEMATIKA
}

\author{
Riki Andriatna ${ }^{1}$, Ira Kurniawati ${ }^{2}$ \\ 1,2Program Studi Pendidikan Matematika, FKIP, Universitas Sebelas Maret \\ email korespondensi: andriatna.riki@ staff.uns.ac.id
}

\begin{tabular}{l} 
Diterima : (12-10-2021), Revisi: (07-12-2021), Diterbitkan : (09-12-2021) \\
\hline ABSTRAK \\
Perkembangan arus informasi mengakibatkan peranan statistika menjadi penting, \\
sehingga memunculkan kemampuan literasi statistik guna menginterpretasikan \\
dan menyimpulkan informasi termasuk mengkritisinya. Literasi statistik merupa- \\
kan kemampuan menginterpretasikan data dan informasi, yang memiliki indikator \\
critical question. Penelitian ini bertujuan untuk mendeskripsikan level literasi sta- \\
tistik mahasiswa calon guru matematika dengan indikator tersebut. Penelitian ini \\
merupakan penelitian kualitatif deskriptif dengan bentuk studi kasus. Subjek pene- \\
litian adalah 21 mahasiswa calon guru matematika. Hasil penelitian menunjukkan \\
bahwa capaian level literasi statistik mahasiswa calon guru matematika yaitu level \\
0-1 (informal/ idiosyncratic) sebanyak 24\%, level 2 (consistent non-critical) seba- \\
nyak 43\%, level 3 (early critical) sebanyak 14\%, dan level 4 (advanced critical) se- \\
banyak 19\%. Hasil tersebut menunjukkan bahwa capaian literasi statistik mahasis- \\
wa calon guru matematika sebagian besar berada pada level consistent non critical. \\
Kata kunci : critical question, level literasi statistik, mahasiswa calon guru matema- \\
tika.
\end{tabular}




\begin{abstract}
The development of the flow of information has resulted in the role of statistics being important, thus giving rise to statistical literacy skills to interpret and conclude information, including critiquing it. Statistical literacy is the ability to interpret data and information, which has a critical question indicator. This study aims to describe the level of statistical literacy of pre-service mathematics teacher with these indicators. This research is a descriptive qualitative in the form of a case study. The research subjects were 21 students of pre-service mathematics teachers. The results showed that the achievement of the statistical literacy level were level 0-1 (infor$\mathrm{mal} /$ idiosyncratic) as much as $24 \%$, level 2 (consistent non-critical) as much as $43 \%$, level 3 (early critical) as much as 14\%, and level 4 (advanced critical) as much as $19 \%$. These results indicate that the statistical literacy achievements of pre-service mathematics teacher are mostly at the consistent non critical level.
\end{abstract}

Key words : critical question, level of statistical literacy, pre-service mathematics teacher.

\title{
Pendahuluan
}

Perkembangan pendidikan selalu mengikuti perubahan zaman dan kebutuhan. Pesatnya perkembangan dan kompleksnya permasalahan dewasa ini membutuhkan keterampilan yang sejalan, yang dikenal dengan keterampilan abad 21 (Kim et al., 2019). Perkembangan abad 21 telah memunculkan keterampilan yang dibutuhkan oleh peserta didik yaitu keterampilan communication, collaboration, complex thinking, dan creativity (Soulé \& Warrick, 2015). Sejalan dengan itu, arus perkembangan informasi dewasa ini sangat pesat sehingga membutuhkan keterampilan dalam memilah, membaca, dan menginterpretasikan informasi (Widjajanti et al., 2018), termasuk bagi dunia pendidikan. Guru dan calon guru merupakan salah satu komponen penting dalam mempersiapkan peserta didik menghadapi tantangan. Hal tersebut menimbulkan adanya kemampuan lain yang dibutuhkan, yaitu literasi statistik yang dapat diasah pada pembelajaran statistika (Ferligoj, 2015).

Statistika adalah pengetahuan yang dimulai dari pengumpulan data sampai pada interpretasinya (Rumsey, 2002; Guven et al., 2021). Sebagaimana matematika, statistika tidak hanya berkaitan dengan operasi perhitungan, tetapi juga mencakup permasalahan-permasalahan dalam kehidupan sehingga memiliki peranan yang penting (Sariningsih \& Herdiman, 2017; Sharma, 2017; Obiral \& Lapinid, 2020). Pada kurikulum Sekolah Menengah di Indonesia, statistika terintegrasi dalam pe- 
lajaran matematika, yang berfokus pada konsep pengumpulan, pengolahan, dan interpretasi data hasil pengamatan. Pada jenjang Perguruan Tinggi statistika berdiri sendiri sehingga menguatkan bahwa statistika memiliki peranan yang penting dalam kehidupan, yang bukan hanya sebatas teori tetapi langsung dipergunakan seperti pada penelitian tugas akhir.

Sejalan dengan hal di atas, fokus dan tujuan pembelajaran statistika menjadi semakin meluas, yaitu memiliki kompetensi sebagai berikut: (1) memahami pentingnya data dan konsep dasar statistika; (2) mengumpulkan dan mendeskripsikan data; (3) menginterpretasikan; dan (4) komunikasi hasil (Rumsey, 2002; Chick \& Pierce, 2012; Setiawan \& Sukoco, 2021). Pentingnya statistika dalam menyelesaikan permasalahan memunculkan kemampuan yang disebut sebagai literasi statistik.

Secara sederhana, literasi statistik diartikan sebagai 'melek' statistika. Literasi statistik merupakan kemampuan dalam interpretasi, evaluasi, dan komunikasi informasi statistik (Gal, 2002; Sharma, 2017; Yuniawatika, 2018). Pada beberapa literatur (Garfield et al., 2010; Garfield dalam Rumsey, 2002) dijelaskan bahwa literasi statistik lebih mengarah pada kemampuan dalam membaca dan menginterpretasikan statistika yang tersaji dalam media massa. Sedangkan Maryati \& Priatna (2018) menyatakan bahwa literasi statistika berkaitan dengan kemampuan pemahaman dan interpretasi yang keduanya merupakan bagian dari kemampuan membaca. Berdasarkan beberapa pengertian tersebut, maka literasi statistik dapat diartikan sebagai kemampuan dalam memahami statistika dan menginterpretasikan termasuk mengkomunikasikannya.

Literasi statistik terdiri dari enam level yang sifatnya hierarki sebagaimana diungkapkan Watson \& Callingham (2003; 2005) sebagai berikut.

Tabel 1. Hierarki Literasi Statistik

\begin{tabular}{ll}
\hline \multicolumn{1}{c}{ Level } & \multicolumn{1}{c}{ Karakteristik } \\
\hline 6 Critical- & Kritis, mempertanyakan keterlibatan konteks, penalaran proporsional \\
Mathematical & $\begin{array}{l}\text { pada konteks media, memperlihatkan apresiasi atas kebutuhan akan } \\
\text { ketidakpastian dalam pembuatan prediksi, dan menafsirkan aspek } \\
\\
\text { halus bahasa }\end{array}$ \\
\hline 5 Critical & Kritis, mempertanyakan keterlibatan konteks yang tidak asing dan \\
& tidak melibatkan penalaran proporsional, tetapi menggunakan \\
& terminologi yang tepat dan memberikan definisi terintegrasi \\
\hline 4 Consistent & Keterlibatan yang sesuai tetapi tidak kritis dengan konteks, \\
\hline
\end{tabular}




\begin{tabular}{ll}
\hline Non-Critical & $\begin{array}{l}\text { penggunaan berbagai aspek terminologi, dan keterampilan statistik } \\
\text { terkait dengan ukuran pemusatan, konsep peluang, dan penyajian data }\end{array}$ \\
\hline 3 Inconsistent & $\begin{array}{l}\text { Keterlibatan selektif dengan konteks, menggunakan format yang } \\
\text { mendukung, penarikan kesimpulan yang tepat tetapi tanpa justifikasi, } \\
\\
\text { dan menggunakan ide statistik secara kualitatif daripada kuantitatif }\end{array}$ \\
\hline 2 Informal & Hanya keterlibatan sehar-hari atau informal dengan konteks dengan \\
& mencerminkan keyakinan intuisi non statistik (konteks terbatas), \\
& fokus pada elemen tunggal dari terminologi dan pengaturan kompleks, \\
& dibatasi pada tabel satu langkah dan perhitungan grafik \\
\hline 1 Idiosyncratic & Keterlibatan idiosinkratik dengan konteks, penggunaan terminologi \\
& tautologis, dan keterampilan matematika dasar terkait dengan \\
& perhitungan satu per satu dan pembacaan nilai sel dalam tabel \\
\hline
\end{tabular}

Model hierarki tersebut menunjukkan proses berpikir dari tahap sederhana sampai tahap kritis. Level 1 dan 2 masih terbatas pada istilah dan makna statistika, level 3 dan 4 sudah menyatakan keterlibatan konteks dan memperlihatkan statistika dalam konteks, dan dua level terakhir menyatakan pemikiran kritis termasuk mempertanyakan kebenaran dalam suatu laporan atau data statistika (Sharma, 2017)

Pada perkembangan selanjutnya, Sharma (2017) menyajikan reduksi terhadap enam level literasi tersebut menjadi empat level yang merujuk pada taksonomi pemikiran Biggs dan Collis. Penggunaan empat level kemampuan literasi berdasarkan Sharma (2017) merujuk pada keterkaitan keempat level tersebut dengan Taksonomi Pemikiran Biggs dan Collis, sehingga setiap level kemampuan akan terkait dengan masing-masing kemampuan pemikiran Biggs dan Collis yang relevan. Adapun keempat level yang dimaksud adalah sebagai berikut (Sharma, 2017).

Tabel 2. Level Kemampuan Literasi Statistik

\begin{tabular}{ll}
\hline \multicolumn{1}{c}{ Level } & \multicolumn{1}{c}{ Karakteristik } \\
\hline 4 Advanced & Keterlibatan kritis dengan mempertanyakan konteks, memiliki \\
Critical & pemahaman mengenai tujuan data dan penyajian data termasuk \\
& $\begin{array}{l}\text { inferensi yang dibuat, keterampilan matematika dikaitkan dengan } \\
\text { masalah kompleks. }\end{array}$ \\
\hline 3 Early Critical & Keterlibatan kritis dalam konteks yang diketahui, termasuk selektif \\
& pada konteks yang belum diketahui yang memerlukan justifikasi, \\
& penggunaan terminologi yang tepat, dan melakukan interpretasi \\
& kualitatif \\
\hline 2 Consistent & Berfokus pada satu aspek relevan atau memperhatikan beberapa as- \\
\hline
\end{tabular}




\begin{tabular}{ll}
\hline Non-Critical & pek relevan, tetapi mengalami kesulitan dalam mengintegrasikannya, \\
& keterlibatan yang tepat tetapi tidak kritis dengan konteks, penggunaan \\
& keterampilan statistika akurat meliputi statistika sederhana dan ka- \\
& rakteristik grafik, perbandingan yang benar secara tunggal atau seba- \\
& gian dibuat dalam tabel atau grafik \\
\hline 0-1Informal/ Idi & Berfokus pada keterlibatan informal dengan konteks dan sering \\
osyncratic & menggunakan ide non statistik yang bersifat intuitif \\
\hline
\end{tabular}

Sejalan dengan perkembangan arus informasi dewasa ini, literasi sangat dibutuhkan oleh peserta didik, guru, dan khususnya calon guru matematika. Perkembangan informasi yang begitu pesat mengharuskan pembaca untuk dapat memilah dan menganalisis sehingga pada akhirnya dapat menginterpretasikannya dengan tepat. Begitu pentingnya literasi statistik dalam kehidupan modern ini (Ridgway et al., 2011; Setiawan \& Sukoco, 2021), maka statistika seharusnya diberikan kepada peserta didik sedini mungkin (NCTM, 2000), termasuk kepada calon guru matematika.

Beberapa penelitian masih menunjukkan rendahnya literasi statistik (Tishkovskaya \& Lancaster, 2010; Yotongyos et al., 2015; Khaerunnisa \& Pamungkas, 2017). Penelitian lain tentang literasi statistik pada beberapa aspek indikator statistika yaitu penalaran terhadap konsep dasar dan istilah statistika dan interpretasi data masih menunjukkan hasil yang belum sesuai harapan untuk mahasiswa calon guru matematika (Andriatna et al., 2021). Penelitian ini bertujuan untuk melihat level literasi statistik agar pada tahapan selanjutnya dapat disusun suatu bahan ajar yang tepat berdasarkan level literasi statistik. Merujuk pada beberapa hasil penelitian di atas maka guru dan calon guru sejatinya diharapkan dapat mencapai level tertinggi dalam literasi statistik, yaitu critical mathematical atau advanced critical sehingga proses pengambilan keputusan menjadi tepat.

\section{Metode Penelitian}

Penelitian ini menggunakan pendekatan kualitatif deskriptif yang bertujuan untuk mendeskripsikan capaian level literasi statistik mahasiswa calon guru matematika dengan bentuk studi kasus. Penelitian melibatkan 21 mahasiswa Program Studi Pendidikan Matematika di salah satu Perguruan Tinggi di Provinsi Jawa Tengah yang dipilih secara acak dan sudah mengambil mata kuliah Metode Statistika. Instrumen penelitian adalah berupa instrumen tes literasi statistik sebanyak satu 
soal yang diadaptasi dari Lane (2014) dengan critical question sebagai salah satu indikator literasi statistik menurut Gal (2004). Hal ini merujuk pada literasi statistik untuk orang dewasa (adults) bahwa indikator literasi statistik, khususnya pada orang dewasa menekankan pada kemampuan mengkritisi informasi statistik terkait data atau argumen (Gal, 2002). Instrumen tersebut divalidasi oleh dua ahli berkaitan dengan isi. Adapun level literasi statistik dalam penelitian ini mengacu pada Sharma (2017) yaitu: (1) Level 0-1 (Informal/Idiosyncratic); (2) Level 2 (Consistent non-critical): (3) Level 3 (Early critical); dan (4) Level 4 (Advanced critical). Berikut adalah instrumen tes kemampuan literasi statistik yang digunakan dalam penelitian (Lane, 2014).

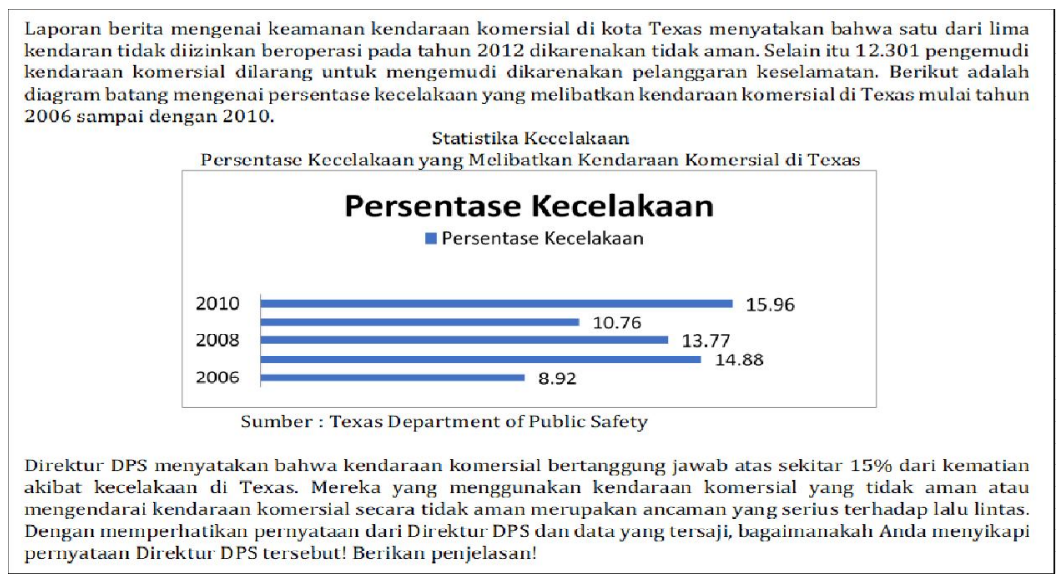

Gambar 1. Instrumen Tes Kemampuan Literasi Statistik

Teknik analisis data mengacu pada Miles \& Huberman (1994) yang memuat reduksi data, penyajian data, serta penarikan kesimpulan dan verifikasi. Adapun keabsahan data dilakukan dengan triangulasi teori.

\section{Hasil dan Pembahasan}

Penelitian melibatkan 21 mahasiswa dari Program Studi Pendidikan Matematika yang sudah mendapatkan mata kuliah Metode Statistika. Instrumen tes yang digunakan merupakan adaptasi dari Lane (2014) dengan indikator literasi statistik critical question. Gal (2002) menyatakan bahwa critical question merupakan bagian dari komponen knowledge element yaitu kemampuan secara kritis dalam mempertanyakan hasil penelitian yang tersaji/ dipublikasikan.

Adapun capaian level literasi statistik mahasiswa calon guru Matematika menunjukkan 91\% mahasiswa calon guru Matematika yang diteliti berada pada level 
yang belum sesuai dengan harapan. Berikut disajikan presentase setiap level literasi statistik yang diperoleh.

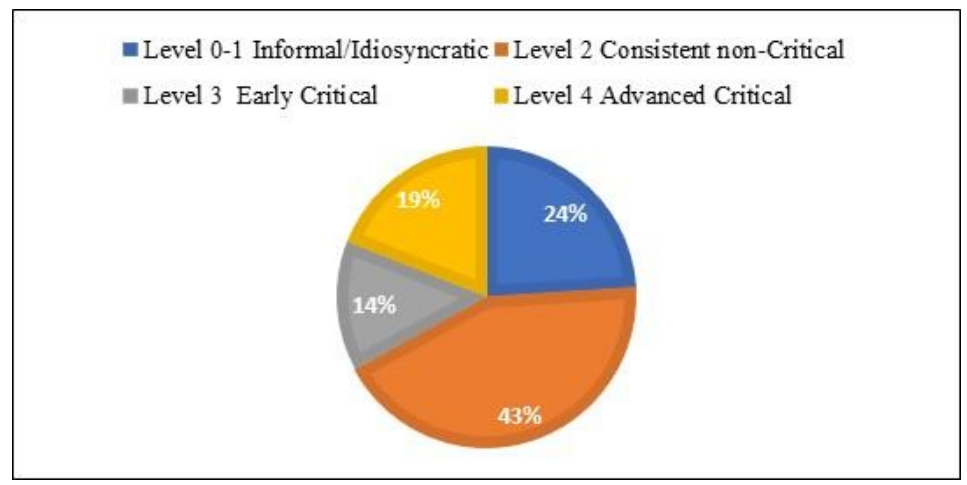

Gambar 2. Capaian Level Kemampuan Literasi Statistik

Gambar 2 menunjukkan bahwa secara kumulatif sebagian besar mahasiswa calon guru Matematika masih berada pada level 0-1 dan 2, yaitu level infor$\mathrm{mal} /$ idiosyncratic dan level consistent non-critical.

\section{Level 0-1 (Informal/Idiosyncratic)}

Data pada gambar 2 menunjukkan mahasiswa yang berada pada level 0-1 (Informal/Idiosyncratic) sebanyak 24\% atau lima dari 21 mahasiswa. Berikut merupakan salah satu contoh jawaban mahasiswa yang berada pada level Informal/ Idiosyncratic.

Saya setuju saja dengan pernyataan Direktur DPS, sebab menurut saya $15 \%$ yang ditanggung sudah lebih dari rata-rata persentase kecelakaan. Rata-rata persentase yang terlibat kecelakaan dari tahun 2010 hingga 2016 yaitu sekitar 12\%, sehingga apabila Direktur DPS akan bertanggung jawab atas 15\% dari kematian akibat kecelakaan itu sudah sudah bisa diterima karena sudah mewakili lainnya.

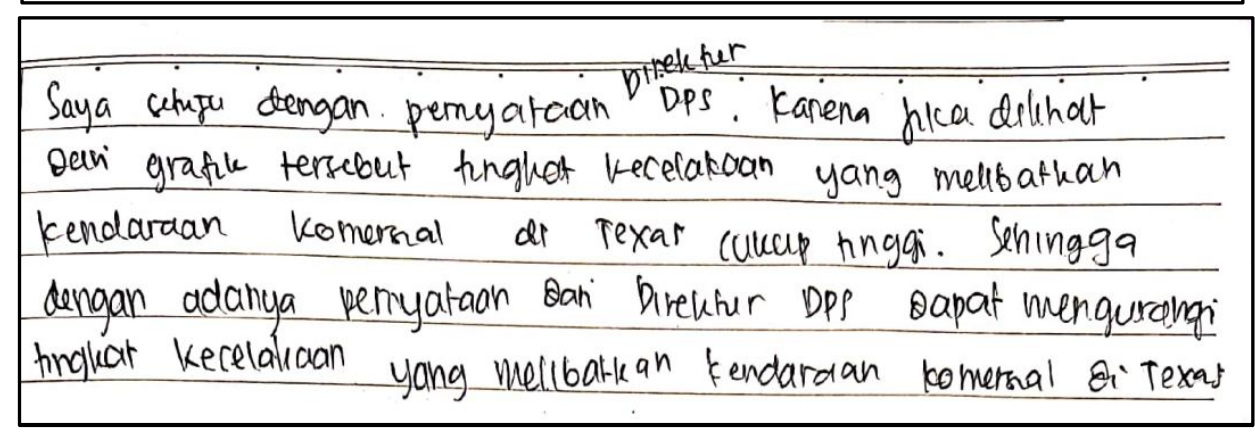

Gambar 3. Jawaban pada Level 0-1 (Informal/ Idiosyncratic)

Pada level informal/idiosyncratic, mahasiswa hanya dapat mengekstrak informasi seperti pada soal, yaitu membaca informasi berdasarkan data pada grafik 
batang, termasuk didalamnya menggunakan penalaran yang bersifat intuitif. Akibatnya mahasiswa menyetujui pendapat yang menyatakan bahwa sebanyak 15\% kematian dikarenakan kecelakan lalu lintas dengan dasar menggunakan kendaran komersial. Sharma (2017) menyatakan bahwa pada level informal/idiosyncratic, seseorang hanya secara langsung mendapatkan informasi dengan melihat data yang tersaji atau membandingkannya, yaitu sebatas berinteraksi dengan bahasa dan istilah dalam statistika.

\section{Level 2 (Consistent non-Critical)}

Berikut merupakan contoh jawaban mahasiswa pada level 2.

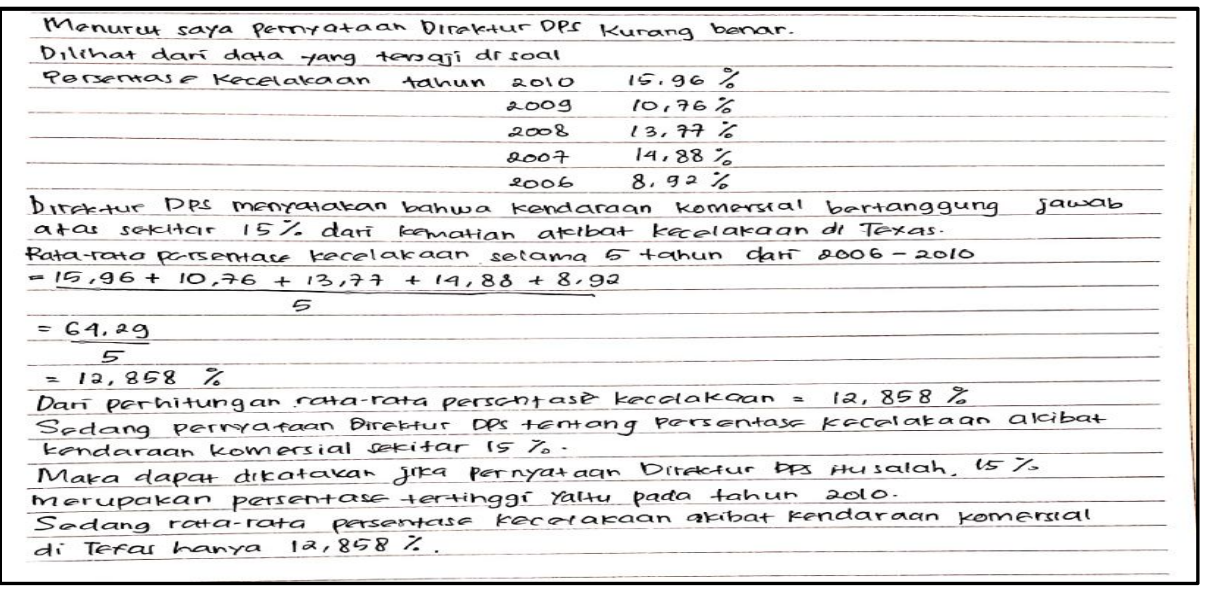

Gambar 4. Jawaban pada Level 2 (Consistent non-Critical)

Gambar 4 menunjukkan bahwa mahasiswa menguatkan pendapatnya dengan menggunakan perhitungan ukuran rata-rata berdasarkan data yang tersaji pada grafik. Berdasarkan hal tersebut, mahasiswa berfokus pada satu aspek dalam menguji kebenaran pernyataan pada soal yang disajikan. Akan tetapi, kebutuhan dalam pengintegrasian konteks tidak menjadi pertimbangan, sehingga alasan pendukung yang disampaikan hanya berfokus pada membandingkan nilai secara deskriptif antara nilai rata-rata yang diperoleh dengan nilai rata-rata yang tersedia pada soal.

Hal tersebut menunjukkan bahwa keterlibatan statistika dirasa sudah tepat, hanya saja tidak kritis terhadap konteks. Sesuai dengan pendapat Sharma (2017) bahwa pada level consistent non-critical, keterampilan statistika dan literasi digunakan dalam memahami masalah, akan tetapi hanya berfokus pada satu aspek yang relevan saja, seperti penyajian data atau ukuran pemusatan data. Pendapat tersebut juga terkait dengan Biggs \& Collis (1982) yang menyebutkan bahwa tahap 
ini berkaitan erat dengan tingkatan taksonomi SOLO pada tahap unistruktural dan multistruktural, yaitu hanya menggunakan sepenggal informasi dengan hubungan sederhana atau pun jika memahami beberapa penggal informasi tetapi masih terpisah satu dengan yang lainnya.

Kondisi tersebut sejalan dengan hasil penelitian Andriatna et al. (2021) yang menyatakan bahwa literasi statistik di level 2 berada pada tahap unistruktural dan multistruktural. Selain itu Setiawan (2019) juga menyebutkan bahwa materi statistika yang tersaji di sekolah, khususnya Sekolah Menengah Atas, memuat level consistent non-critical Hal ini menunjukkan bahwa perlunya peningkatan literasi statistik mahasiswa calon guru matematika.

\section{Level 3 (Early Critical)}

Data pada gambar 2 menunjukkan bahwa jumlah mahasiswa yang mencapai level 3 literasi statistik adalah 14\% atau sebanyak tiga dari 21 mahasiswa. Berikut merupakan salah satu jawaban mahasiswa pada level 3.

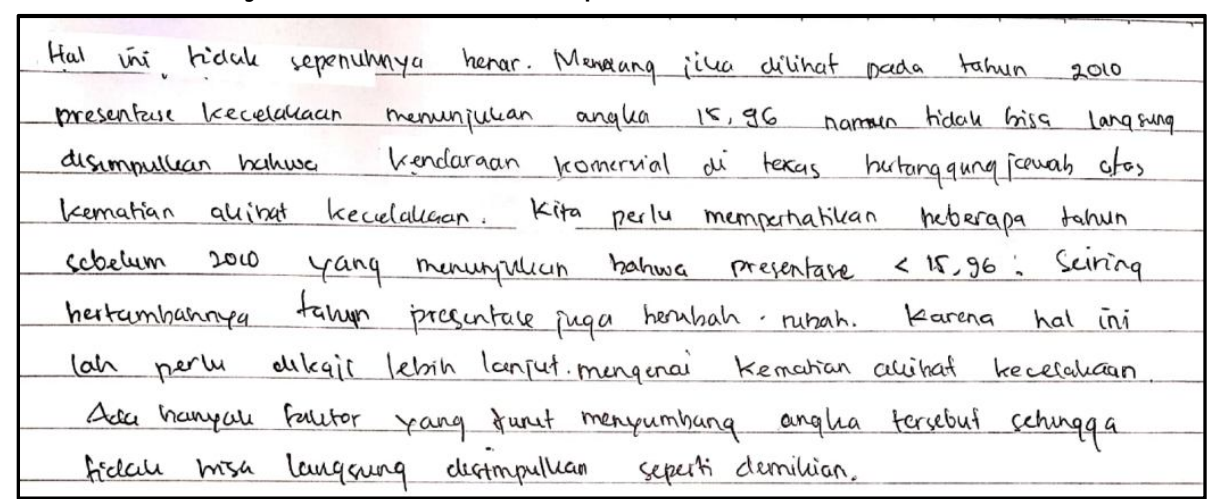

Gambar 5. Jawaban pada Level 3 (Early Critical)

Level 3 atau level awal kritis menunjukkan adanya keterlibatan kritis dan selektif terhadap konteks, termasuk mempertanyakan keterwakilan data yang tersaji. Gambar 5 menunjukkan bahwa mahasiswa tidak setuju dengan pendapat yang disajikan pada soal dengan mempertanyakan keterlibatan data lainnya yang tidak tersaji. Sharma (2017) menyatakan bahwa pada level ini, karakteristik berpikir relational dari Taksonomi SOLO sudah mulai diperlihatkan, yaitu adanya perhatian terhadap beberapa aspek yang relevan dalam soal. Keterlibatan beberapa aspek yang dimaksud terlihat pada jawaban mahasiswa yang tidak hanya berfokus pada data-data yang tersaji pada diagram batang, melainkan mempertanyakan aspek lain yang mendasari munculnya pernyataan dari Direktur DPS. Meskipun demikian, mahasiswa belum secara mendalam dan kritis mempertanyakan keterlibatan fak- 
tor lain yang dimaksud yang tidak diungkap pada diagram batang yang tersaji, termasuk melibatkannya dengan informasi atau konteks yang tersedia.

\section{Level 4 (Advanced Critical)}

Data pada gambar 2 menunjukkan bahwa pada level 4 (advanced critical) terdapat sebanyak empat dari 21 mahasiswa. Berikut disajikan contoh jawaban mahasiswa pada level 4.

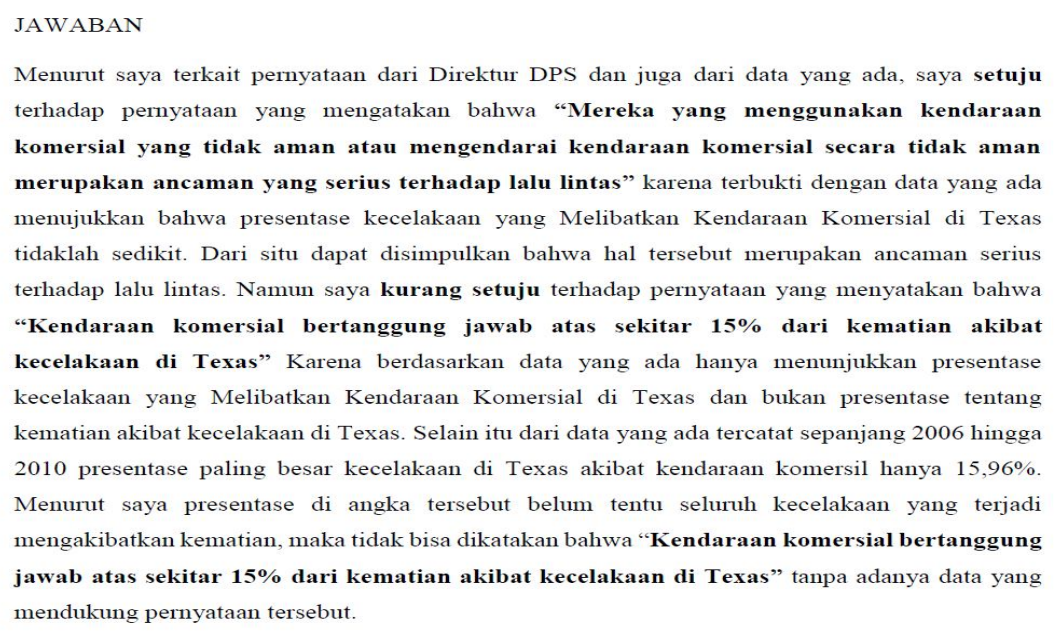

Gambar 6. Jawaban pada Level 4AdvancedCritical

Gambar 6 menunjukkan adanya keterlibatan kritis dan mempertanyakan konteks dalam rangka mendapatkan kebenaran informasi yang disajikan. Persentase kematian sebanyak 15\% yang disebabkan oleh kendaraan komersial disangsikan karena tidak adanya data pendukung yang kuat, termasuk data yang disajikan. Selain itu, diagram menunjukkan data kecelakaan lalu lintas yang melibatkan kendaraan komersial, sedangkan pernyataan berkaitan dengan persentase kematian, termasuk tidak adanya informasi yang menggambarkan persentase jumlah kendaaran komersial pada rentang waktu tahun 2006 sampai dengan tahun 2010. Menurut Sharma (2017) hal tersebut menunjukkan adanya keterlibatan konteks dan mempertanyakan secara kritis, termasuk pengintegrasian pengetahuan statistika dan kontekstual yang menunjukkan pemikiran abstrak.

Ditinjau dari sudut pandang indikator critical question, mahasiswa sudah menunjukkan adanya kritisisasi terhadap hasil yang dipublikasikan. Gal (2004) menyatakan bahwa indikator literasi statistik, khususnya pada orang dewasa menekankan pada kemampuan mengkritisi informasi statistik terkait data atau argu- 
men statistika yang disajikan. Meskipun demikian, jika melihat secara keseluruhan terhadap capaian level literasi statistika, mahasiswa yang mencapai level 3 dan 4 masih belum sepenuhnya sesuai dengan harapan. Merujuk pada perkembangan informasi yang cepat saat ini, diperlukan kemampuan kritis yang tinggi sehingga dapat memberikan interpretasi data dan kesimpulan yang valid. Begitupun dalam tataran pendidikan, guru dan siswa perlu berada pada level tertinggi literasi statistik, yaitu advanced critical atau critical mathematical. Sejalan dengan itu, kemampuan dalam analisis dan interpretasi data pada jenjang Pendidikan Menengah diharapkan akan tercapai menggunakan penalaran proporsional yang lengkap, termasuk membuat inferensi berdasarkan data dan konteks (Jones \& Thornton dalam Setiawan, 2019).

Peningkatan kualitas pembelajaran statistika, salah satunya, dapat menjadiperbaikan dalam meningkatkan level literasi statistik (Setiawan \& Sukoco, 2021). Kegiatan pembelajaran tidak hanya diarahakan komputasi statistika semata (Tiro, 2018), tetapi juga pada literasi statistik (Abidin et al., 2017). Literasi statistik dihadirkan dalam setiap kegiatan pembelajaran, sehingga pemahaman yang mendalam akan statistika menjadi semakin kuat.

\section{Kesimpulan}

Capaian level literasi statistik mahasiswa calon guru matematika berdasarkan hasil yang diperoleh menujukkan hasil sebanyak 24\% mahasiswa berada pada level 0-1 (informal/idiosyncratic), level 2 (consistent non critical) sebanyak 43\%, level 3 (early critical) sebanyak 14\%, dan level 4 (advanced critical) sebanyak 19\%. Hasil tersebut menunjukkan bahwa capaian literasi statistik mahasiswa calon guru matematika berada pada level consistent non critical. Meskipun demikian, terdapat empat dari 21 mahasiswa berada pada tahap tertinggi dari level kemampuan literasi statistik yaitu advanced critical. Hasil yang diperoleh, memberikan gambaran kepada instansi mengenai capaian level literasi statistik mahasiswa calon guru Matematika. Sehingga diharapkan adanya modifikasi dan/ atau penambahan aktivitas pembelajaran yang menekankan pada literasi statistik. Salah satu keterbatasan dalam penelitian ini adalah jumlah mahasiswa yang terlibat masih relatif sedikit. Sehingga diharapkan penelitian selanjutnya dapat dilakukan dengan melibatkan mahasiswa yang lebih banyak dan beragam, salah satunya berdasarkan le- 
tak geografis sehingga mendapatkan gambaran secara menyeluruh dan mendalam tentang level literasi statistik mahasiswa calon guru Matematika di Indonesia. Berdasarkan hasil yang diperoleh, baik kiranya jika ada tindak lanjut dalam rangka peningkatan level literasi statistik dari mahasiswa calon guru matematika.

\section{Daftar Pustaka}

Abidin, Y., Mulyati, T., \& Yunansah, H. (2017). Developing Literacy Learning Model Based on Multi Literacy, Integrated, and Differentiated Concept At Primary School.Jurnal Cakrawala Pendidikan, 36(2), 156-166.

Andriatna, R., Kurniawati, I., \& Wulandari, A. N. (2021). Profil Kemampuan Literasi Statistik Mahasiswa Calon Guru Matematika. FIBONACCI: Jurnal Pendidikan Matematika Dan Matematika, 7(1), 19-28. https:/ / doi.org/ 10.24853/ fbc.7.1.19-28.

Biggs, J., \& Collis, K. F. (1982). Evaluating the Quality of Learning: the SOLO Taxonomy. New York: Academic Press.

Chick, H. L., \& Pierce, R. (2012). TEACHING FOR STATISTICAL LITERACY: UTILISING AFFORDANCES IN REAL-WORLD DATA. International Journal of Science and Mathematics Education, 10(2), 339-362. https:// doi.org/ 10.1007/ s10763-011-9303-2.

Ferligoj, A. (2015). How to improve statistical literacy? Metodoloski Zvezki, 12(1), $1-10$.

Gal, I. (2002). Adults' statistical literacy: Meanings, components, responsibilities. International Statistical Review, 70(1), 1-25. https:// doi.org/ 10.1111/j.1751-5823.2002.tb00336.x.

Gal, I. (2004). Statistical Literacy: Meaning, Components, Responsibilities. In D. Ben-Zevi \& J. Garfiled (Eds.), The Challenge of Developing Statistical Literacy, Reasoning, and Thinking. Boston: Kluwer Academic Publishers.

Garfield, J., DelMas, R., \& Zieffler, A. (2010). Assesing Statistical Thinking. In N. H. P. Bidgood \& F. Jolliffe (Eds.), Assesment Methods in Statistical Education: An International Perspective (pp. 175-186). Milton: John Wiley \& Sons.

Guven, B., Baki, A., Uzun, N., Ozmen, Z. M., \& Arslan, Z. (2021). Evaluating the Statistics Courses in Terms of the Statistical Literacy: Didactic Pathways of Pre-Service Mathematics Teachers. International Electronic Journal of Mathematics Education, 16(2), em0627. https:/ / doi.org/ 10.29333/ iejme/ 9769.

Khaerunnisa, E., \& Pamungkas, A. S. (2017). Profil Kemampuan Literasi Statistis Mahasiswa Jurusan Pendidikan Matematika Universitas Sultan Ageng Tirtayasa. AKSIOMA: Jurnal Program Studi Pendidikan Matematika, 6(2), 246-255. 
https:/ / doi.org/ 10.24127/ ajpm.v6i2.970.

Kim, S., Raza, M., \& Seidman, E. (2019). Improving 21st-century teaching skills: The key to effective 21st-century learners. Research in Comparative and International Education, 14(1), 99-117. https:/ / doi.org/ 10.1177/ 1745499919829214.

Lane, D. M. (2014). Online Statistics Education: An Interactive Multimedia Course of Study. Retrieved July 23, 2020, from http:/ / onlinestatbook.com/2/ graphing_distributions/graphing_distributionsSA .html.

Maryati, I., \& Priatna, N. (2018). Analisis Kemampuan Literasi Statistis Siswa Madrasah Tsanawiyah dalam Materi Statistika. Journal of Medives: Journal of Mathematics Education IKIP Veteran Semarang, 2(2), 205. https:// doi.org/ 10.31331/ medives.v2i2.640.

Miles, M. B., \& Huberman, A. M. (1994). Qualitative Data Analysis: An Expanded Sourcebook (2nd ed.). Sage Publications.

NCTM. (2000). Principles and Standards fo School Matematics. Reston, VA : National Council of Teachers of Mathematics.

Obiral, J. T., \& Lapinid, M. R. . (2020). No TitleThe Use of Statistical Investigation in Assessing Students'Performance in Statistics. Action Research and Innovation in Science Education, 3(2), 47-54.

Ridgway, J., Nicholson, J., \& McCusker, S. (2011). Developing Statistical Literacy in Students and Teachers. In C. Batanero, G. Burrill, \& C. Reading (Eds.), Teaching Statistics in School Mathematics-Challenges for Teaching and Teacher Education. (pp.311-322). Springer. https:/ / doi.org/ 10.1007/ 978-94-007-1131-0_30.

Rumsey, D. J. (2002). Statistical literacy as a goal for introductory statistics courses. Journal of Statistics Education, 10(3). https:// doi.org/ 10.1080/ 10691898.2002.11910678.

Sariningsih, R., \& Herdiman, I. (2017). Mengembangkan kemampuan penalaran statistik dan berpikir kreatif matematis mahasiswa di Kota Cimahi melalui pendekatan open-ended. Jurnal Riset Pendidikan Matematika, 4(2), 239. https:/ / doi.org/ 10.21831/jrpm.v4i2.16685.

Setiawan, E. P. (2019). Analisis muatan literasi statistika dalam buku teks matematika Kurikulum 2013. Pythagoras: Jurnal Pendidikan Matematika, 14(2), 163-177. https:/ / doi.org/ 10.21831/ pg.v14i2.28558.

Setiawan, E. P., \& Sukoco, H. (2021). Exploring first year university students' statistical literacy: A case on describing and visualizing data. Journal on Mathematics Education, 12(3), 427-448. https:/ / doi.org/ 10.22342/ JME.12.3.13202.427-448.

Sharma, S. (2017). Definitions and models of statistical literacy: a literature review. 
Open Review of Educational Research, 4(1), 118-133. https:// doi.org/ 10.1080/ 23265507.2017.1354313.

Soulé, H., \& Warrick, T. (2015). Defining 21st century readiness for all students: What we know and how to get there. Psychology of Aesthetics, Creativity, and the Arts, 9(2), 178-186. https:// doi.org/ 10.1037/ aca0000017.

Tiro, M. A. (2018). National Movement for Statistical Literacy in Indonesia: An Idea. Journal of Physics: Conference Series, 1028(1), 0-8. https:/ / doi.org/ 10.1088/ 1742-6596/ 1028/ 1/ 012216.

Tishkovskaya, S., \& Lancaster, G. A. (2010). Teaching Strategies to Promote Statistical Literacy: Review and Implementation. In C.Reading (Ed.), International Conference on Teaching Statistics. International Statistical Institute.

Watson, J., \& Callingham, R. (2003). Statistical literacy: A complex hierarchical construct. Statistics Education Research Journal, 2(2), 3-46. http:/ / www.stat.auckland.ac.nz/ iase/ serj/ SERJ2(2)_Watson_Callingham.pdf.

Watson, J. M., \& Callingham, R. A. (2005). Statistical literacy: From idiosyncratic to critical thinking. In G. Burrill \& M. Camden (Eds.), Curricular Development in Statistics Education (pp. 116-162). International Statistical Institute.

Widjajanti, D. B., Listyani, E., Susanti, M., \& Setyaningrum, W. (2018). Examining Prospective Teachersr Mathematical Communication Skills in Statistics. Proceedings of the 1st Annual International Conference on Mathematics, Science, and Education (ICOMSE 2017), 218, 231-235. https:// doi.org/ 10.2991/ icomse-17.2018.41.

Yotongyos, M., Traiwichitkhun, D., \& Kaemkate, W. (2015). Undergraduate Students' Statistical Literacy: A Survey Study. Procedia - Social and Behavioral Sciences, 191(July), 2731-2734. https:/ / doi.org/ 10.1016/ j.sbspro.2015.04.328.

Yuniawatika. (2018). Statistical Literacy and its Urgency for Students. In D. E. Kusumaningrum (Ed.), Proceedings of the 3rd International Conference on Education Management and Administration (CoEMA 2018) (pp. 170-173). Universitas Negeri Malang. https:// doi.org/ 10.2991/ coema-18.2018.41. 